\title{
У INTERTEXTUALITY, ISIAC FEATURES, AND THE SHAPING OF THE SACRED FEMININE IN THE TRIMORPHIC PROTENNOIA (NHC XIII, 1)
}

\author{
Nicolò Sassi \\ Indiana University - Bloomington
}

\begin{abstract}
The aim of this paper is to bring to light through intertextual analysis some dimensions of continuity between the Hellenistic and Imperial theology of Isis and the figure of the Sacred Feminine as it appears in the Trimorphic Protennoia (NHC XIII, 1). Instead of attempting to establish a diachronic (=historical) relationship of dependence between sources (e.g., borrowing, allusion, influence), this study establishes correspondences that can be traced on the literary level. Through a reception-oriented analysis, it will be possible to show the continuity between the Isiac religion and the late ancient mysticism of the Trimorphic Protennoia. A late ancient reader would have experienced the Nag Hammadi text in dialogue with Isiac traditions, and this literary dialogue with the Isiac religion would have nurtured and shaped their understanding of the sacred feminine described in the Trimorphic Protennoia.
\end{abstract}

\section{INTRODUCTION}

Although, as Turcan (1989:77-78) wrote, "les Grecs de Naucratis et, avant eux sans doute aussi, les marins phéniciens avaient commercialisé des scarabées, des amulettes, des statuettes, des oushabtis, des vases plastiques et autres articles de pacotille certes, mais qui divulguaient en Sicile, en Sardaigne et jusqu'en Espagne l'imagerie des dieux nilotiques," major phenomena of inter-contamination between the Egyptian cults and other ancient Mediterranean religions did not take place until after the conquests of Alexander and the enthronement of the Ptolemaic dynasty. ${ }^{1}$ After that, the spread of these cults - and the consequent cross-religious fertilization with other spiritual traditions - was massive. The cult of Isis, in particular, reached many major centers of the Mediterranean world. From its Egyptian locus nativus it spread toward the Oriental Greek islands of Lesbos, Kos, Rhodes, Crete, Cyprus, and Delos; it subsequently reached the main cities of continental Greece, from Argos and Mantinea to Sicyon, Corinth, Delphi, and to the northern cities

\footnotetext{
1 I want to thank here the many scholars who have provided insightful suggestions and feedback on this work: Sonia Velázquez and Jeremy Schott in primis for our stimulating discussions on intertextuality, Barthes, and Bakhtin; Alessandra Sarra, Jacob Boss, John Purcell, and Maggie Slaughter for their helpful feedback on this project in its initial stages; Emanuel Fiano, for discussing with me some issues of the Coptic text of the Trimorphic Protennoia; and the editor and the anonymous peer reviewers of Studia Orientalia Electronica for dedicating time to my work and for providing precious insights and constructive feedback.
}

Volume 7 (2019), pp. 82-95

DOI $10.23993 /$ store. 76643

Licensed under Creative Commons Attribution 3.0 License.

ISSN: 2323-5209

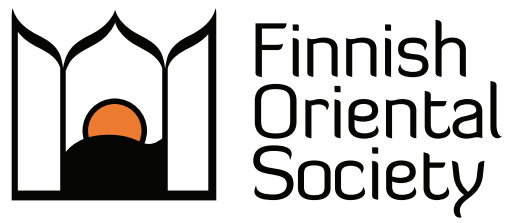


of Thracia and Macedonia; by the end of the second century BCE, traces of the cult of Isis could be found from the Western coasts of the Black Sea to the southern and central regions of Italy - above all in Sicily and in Rome (Turcan 1989: 83-86; see also Baechler 1959; Tran-Tam-Tinh 1964; 1972a; 1972b; Malaise 1972; Dewandel 1941-1942; Takács 1994). Greeks, Anatolians, Jews, Romans, and later Christians came in contact with the rituals, myths, and prayers of the cult of Isis. Examples of this phenomenon can be found, among other places, in biblical texts of the Hellenistic period such as the book of Proverbs ${ }^{2}$ or the Book of Ben Sira. ${ }^{3}$ The worship of Isis flourished for centuries, and it was not effectively suppressed until the sixth century (Heyob 1975: 53; Streete 2000:370).

The aim of this paper is to bring to light through intertextual analysis several dimensions of continuity between the Hellenistic and Imperial theology of Isis and the figure of the Sacred Feminine as it appears in the Trimorphic Protennoia (NHC XIII, 1). ${ }^{4}$ An intertextual approach appears particularly useful in this context. Textual relations and interdependencies in late antiquity are complex and often almost impossible to map out. Nonetheless, as Nikaido (2001: 219-242) has shown in his work on the figure of Ishmael and Hagar in Genesis, "the usefulness of the intertextual approach [...] is that it provides a theoretical basis for dealing with textual similarities that, on one hand, cannot be readily be labeled as 'borrowed' (e.g. citations) but, on the other hand, are obviously more than mere happenstance." Instead of attempting to establish a diachronic, phylogenetic relationship of dependence between sources (e.g. borrowing, allusion, influence), this study establishes the correspondences that can be traced on a literary level in order to clarify and illuminate how, from a reader-centered perspective, the echoes of earlier sacred textual traditions added layers of meaning to the text of Trim. Prot., thus engaging the late ancient reader-responder with a broader constellation of religious literatures than just a single discrete text. ${ }^{5}$ By summoning literary reminiscences of another religious tradition, these textual correspondences affected and informed the late ancient reader's interpretation

\footnotetext{
2 Cf. Proverbs 8. The period of composition of the book of Proverbs is notoriously hard to determine. What seems to be moderately certain, though, is that the first section of the book (chapters 1-9) is the most recent, and several scholars (e.g. Oesterley, Gordis) have proposed the third and second centuries BCE as the most probable period of composition. A synthesis of the scholarship on this theme can be found in Whybray 1995: $150 \mathrm{ff}$.

3 The influence of Egyptian elements on the biblical texts of the Hellenistic period is disputed by scholars. There have been enthusiastic supporters of this thesis (see Prato 1998: 129-151; Conzelmann 1964:225-234; Hengel 1969: 284-292; Marböck 1999), as well as opposers (see Sanders 1982: 73-78).

4 Trimorphic Protennoia from now on Trim. Prot. Text Facsimile: Robinson 1984, XV: 105-120. Critical edition: Hedrick 1990:371-454 (all quotes given according to this edition). Translation: Meyer 2007. On the literary level, this text does seem to belong to any of the literary genres found in the other texts of the Nag Hammadi corpus. It could arguably be described as a prosimetrum, namely, a poetic composition that exploits a combination of verse and prose. The poetic sections of Trim. Prot. constitute a sustained first-person hymn of self-predication in which the obscure figure of Protennoia, a sort of primeval mind or thought of the Godhead, sings about her manifestations in the universe and her role in creation. The text is composed of three sections: the first one is a cosmological treatise about the first manifestation of Protennoia as Thought of the Father $(35,1-42,3)$; the second section is an eschatological treatise about the manifestation of Protennoia as Voice of the Mother $(42,4-46,4)$; the third and last section is a soteriological treatise that deals with the manifestation of the Logos of the Son (46, $5-50,21)$. For a brief introduction to the main themes and main philological, theological, and literary problems of the text, see Denzey Lewis 2012. For a more sustained investigation of these same topics, see the monumental introduction and commentary to the critical edition of the text written by Paul-Hubert Poirier (2006). Another general historical assessment of the treatise is found in Turner 1988:511-513.

5 I follow in this methodology the model of the works by Chance (1998) and Dodson (2002:39-52), respectively, on the intertextual relationships between Xenophon's Ephesian Tales and the Acts of the Apostles, and the ancient novel and the Gospel of Matthew.
} 
and experience of Trim. Prot.; it is this experience, and its significance for the interpretation of Trim. Prot. as a historical and literary phenomenon that I seek to discuss here.

Recent studies in historical sociolinguistic philology have shown that in order to achieve a more fully contextualized account and interpretation of premodern texts and their meaning, scholars need to acknowledge the "layered simultaneity" of discourse and contexts present in texts (Soukup 2017:673-678; Nevalainen 2015:243-269; Nevalainen \& Raumolin-Brunberg 2012:22-40). This means acknowledging how the experience of a text and its meaning are the result of an active, emergent, and ongoing process of meaning-making in which the immediate historical and on-the-ground-level social context of the readership plays a constitutive role (see Bakhtin 1986: 60-102; Gumperz 1982; 2001:215-228; Erickson 1986:294-319).

In the context of the present analysis, this theoretical framework sheds new light on the intertextual correspondences between Isiac literature and Trim. Prot. and on their significance for the interpretation of this Nag Hammadi treatise. Within the context of the widespread dissemination of the Isiac cult in the second, third, and fourth centuries of the Common Era, a reader in the Imperial period and late antiquity would have perceived multiple similarities between Isiac literature and Trim. Prot., which would have led them to experience Trim. Prot. in dialogue with Isiac traditions. This literary dialogue would have nurtured and shaped their understanding of the sacred feminine described in the Nag Hammadi treatise, thus creating a form of syncretism resulting from the literary overlap between the two figures presented in the texts.

The immediate goal of this socio-linguistically informed exploration is to illuminate the neglected dimension of continuity between Isiac literature and Trim. Prot., between the Hellenistic Egyptian cultic past and the mystical present of the Nag Hammadi treatise, in order to further reveal the continuum between the two religious worlds. ${ }^{6}$ Unlike other religious traditions mirrored in Trim. Prot., the relationship between this text and the Egyptian religion has been little studied. Nearly all the work that has investigated the relationship between the imagery of Trim. Prot. and previous and contemporary literature has delved into the deployment of Jewish wisdom traditions (cf. 1 Enoch 42, Ben Sira 24, Wisdom of Solomon 7-8), presenting Wisdom as a hypostasis of the sacred feminine. ${ }^{7}$ On the other hand, little scholarship has explored the continuities between the Nag Hammadi scriptures and the Isiac cults, and even less has focused on the relationship between these cults and Trim. Prot. specifically.

Scholarship on the use of Isiac imagery in the Nag Hammadi scriptures has focused on three texts: Thunder: Perfect Mind (NHC VI, 2), the Pronoia hymn contained in the Apocryphon of John (NHC II, 1; III, 1; IV, 1; Codex Papyrus Berolinensis 8502), and obviously Trim. Prot. Poirier (1995: 153-157), MacRae (1970:122-134), and more recently Halvgaard (2012) have pointed to some formal similarities between Isiac literature and these Nag Hammadi texts, but ultimately

\footnotetext{
6 Unlike the religious milieu of origin of Isiac aretalogies described above, the religious world in which Trim. Prot. was written appears much more difficult to identify. The fact that Trim. Prot. is an anonymous work with no references to known realities, events, or people makes it difficult to be situated geographically and chronologically. On palaeographical grounds, we can situate the terminus ante quem of the composition of the work around the half of the fourth century. All attempts to establish the terminus post quem must rely on internal elements. On account of the relationship of Trim. Prot. with the Apocryphon of John (NHC II, 1) and other Christian and Jewish traditions, Poirier (2006:67-122) hypothesized that the composition of Trim. Prot. took place in the first half of the third century in the Christian milieu of an Eastern Mediterranean region such as Egypt or Syria. 7 The seminal works in this field are MacRae (1986) and Turner (1988:511-513). MacRae and Turner believe that the figure of Protennoia depends to a significant extent on Jewish wisdom traditions. The hypothesis of MacRae and Turner has been contested by Nicola Denzey Lewis (2001:20-44), who bases her argument on the earlier work of Jarl Fossum (1995: 117-133).
} 
established that within the context of an investigation on potential models and sources of the Nag Hammadi corpus, "les aretalogies et les autres 'isiaca' ne peuvent fournir la clef de l'interprétation" (Poirier 1995:156). As far as Trim. Prot. is concerned, in his monumental investigation of the history of scholarship on this treatise, Poirier (2006:33-67) found only two articles that specifically mention the relationship between Trim. Prot. and Isiac traditions, but neither of them manage to provide a systematic explanation of the significance of the formal similarities between the two corpora of religious literature. The first one, by Schenke (1974: col. 731-746), argues that the divine feminine in Trim. Prot. is based on the model of the universal goddess embodied by the Isis-Selene-Sophia triptych, and consequently does not focus on the specific Isis-Protennoia relationship. The second one, by Turner (2006:941-992), detects similarities between the ritual model described in Trim. Prot. and the initiation ritual described by Apuleius in the eleventh book of his Metamorphoses, but again, no explanation or hypothesis is provided regarding the possible origins or significance of such similarities. Turner (2000, V:384) as well, in his edition and translation of the Nag Hammadi codices IX-XIII describes, albeit rather briefly, the formal similarities shared by Isis in the aretalogical passages found in Diodorus Siculus (Bibl. Hist. I.27.3-5) and the aretalogy of Kyme analyzed below. In conclusion, although the formal similarities between Trim. Prot. and some aretalogical literature has long been noted by scholars, no study has investigated the relationship between form and function in these shared passages, nor has any made a case for the significance of these similarities for the interpretation of Trim. Prot. within the historical context of its composition and fruition. The following analysis aims to represent a seminal contribution in this sense.

The Isiac literature that I will investigate consists mostly of Greek and Graeco-Egyptian aretalogies of the Hellenistic and early Imperial periods (Isidor of Fayum's Hymns, the anonymous Hymns of Philae, Apuleius' eleventh book of the Metamorphoses, Aretalogy of Maronea, Aretalogy of Kyme), but it also includes more ancient Egyptian magical texts (the Papyrus Turin 1993 and the Book of the Dead).

In order to support my argument, I will leverage the following evidence of intertextual relations between Trim. Prot. and Isiac literature:

1) Aretalogical poetical form (first-person hymn of self-predication)

2) Features of the sacred feminine:

a) Wisdom goddess

b) Polyonymy

c) Originary goddess

d) Universal goddess, Being of beings

3) Echo of a тó $\pi$ os of earlier Isiac aretalogies

Since the first of these similarities has already been detected by Turner, as mentioned above, I will focus my analysis on points 2 and 3. Besides shedding light on intertextuality as a textual way of religious intersection between the Isiac tradition and Trim. Prot., this exploration aims to provide a thorough investigation and categorization of the literary parallels between the two text beyond the already identified continuity in the literary form. 


\section{FEATURES OF THE SACRED FEMININE}

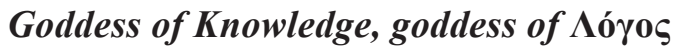

Since at least Dynasty XIX (beginning in the thirteenth century BCE), Isis has been associated with ideas of knowledge (especially of magic and medicine) and omniscience. A papyrus (P. Turin 1993) dating back to that period contains a passage in which Isis is described as a goddess of knowledge: " "Now, Isis was a wise woman. Her heart was more devious than millions among men; she was more selective than millions among the gods; she was more exacting than millions among the blessed dead. There was nothing that she did not know in heaven or earth, like Re, who made the substance of the earth" (Borghouts 1978:51). Isis' omniscience described in this last sentence appears to be mirrored in the figure of Protennoia: "I counsel those who are hidden, since I know everything that exists in the All." Moreover, the name Protennoia itself (прUTENNOIa), with its relation to the semantic universe of the verb voć $\omega$ ('perceive by the mind', 'apprehend', 'think', et al.), ${ }^{10}$ is deeply linked to wisdom and knowledge.

\section{Polyonymy: a goddess of many names}

The sacred feminine who speaks in Trim. Prot. describes herself as a divinity of many names: "[She] is called by three names, though she dwells alone." "She is called Protennoia, Barbēlo (38, 9: варвндс), Meirothea (38, 15: мєіроөєа), Mother $(38,13)$, Father $(45,3)$, Incomprehensible Uterus $(38,15)$, Virgin $(38,14)$, and Perfect Glory $(38,9)$. Polyonymy is also a typical characteristic of Isis. ${ }^{12}$ Throughout the millenary history of her cult, Isis came to be known by a variety of names, describing the many loci of her worship (Isis Lochia, Isis Pharia), her role of mater (Isis lactans, one of her most ancient iconographic characterizations) and protector (Isis Euploia), her status among the gods (Isis mater deorum), as well as her assimilations with other deities. Herodotus (Histories II, 59), for instance, describes this phenomenon, writing ' $\mathrm{I} \sigma 1 \varsigma \delta \grave{\varepsilon}$

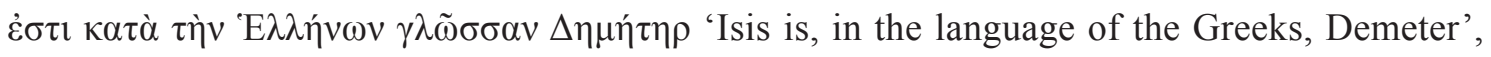
thus assimilating the Egyptian goddess to the Greek goddess of the earth and the harvest. It is not possible here to analyze in depth the variety and evolution of Isis' shifting identity; nor is necessary, as this complex history has already been thoroughly investigated. ${ }^{13}$ Here I will limit my exploration to a few examples drawn from aretalogical literature.

In the Metamorphoses, Apuleius writes a long passage on the many names that Isis is called:

[...] cuius numen unicum multiformi specie, ritu vario, nomine multiiugo totus veneratur orbis.

Inde primigenii Phryges Pessinuntiam deum matrem, hinc autocthones Attici Cecropeiam

Minervam, illinc fluctuantes Cyprii Paphiam Venerem, Cretes sagittiferi Dictynnam Dianam, Siculi

trilingues Ortygiam Proserpinam, Eleusinii vetusti Actaeam Cererem, Iunonem alii, Bellonam alii,

\footnotetext{
8 A facsimile of the P. Turin 1993 can be found in Pleyte \& Rossi 1869-1876; the translation used here is that of J.F. Borghouts (1978).

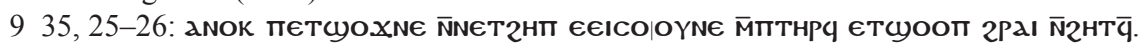

10 See the Liddle-Scott-Jones lexicon s.v. voć

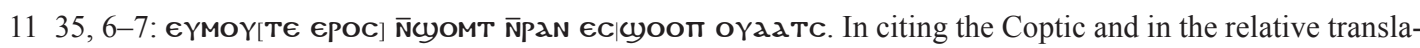
tions, I will maintain all the emendationes ope ingenii of the editor.

12 Ancient Mediterranean gods who, among others, share this peculiar features are Zeus, Dionysius, Apollo, and Selene. About this phenomenon in the ancient Mediterranean world, see Croy 2014:27-43.

13 For a taxonomy of Isiac names and epithets, accompanied by a systematic investigation of their origins as well as of the ancient sources that record them, see Malaise 2005. A list of Isis' names and epithets can be found in the index at the end of the volume.
} 
Hecatam isti, Rhamnusiam illi, et qui nascentis dei Solis incohantibus illustrantur radiis Aethiopes utrique priscaque doctrina pollentes Aegyptii, caerimoniis me propriis percolentes, appellant vero nomine reginam Isidem (XI 5).

My divinity is one, worshipped by all the world under different forms, with various rites, and by manifold names. In one place the Phrygians, first-born of men, call me Pessinuntine Mother of the Gods, in another the autochthonous people of Attica call me Cecropian Minerva, in another the sea-washed Cyprians call me Paphian Venus; to the arrow-bearing Cretans I am Dictynna Diana, to the trilingual Sicilians Ortygian Proserpina, to the ancient people of Eleusis Attic Ceres; some call me Juno, some Bellona, others Hecate, and still others Rhamnusia; the people of the two Ethiopias, who are lighted by the first rays of the Sun-God as he rises every day, and the Egyptians, who are strong in ancient lore, worship me with the rites that are truly mine and call me by my real name, which is Queen Isis. ${ }^{14}$

In aretalogical literature, there is a record of this Isiac feature in the second- to first-century BCE(?) hymn to Isis written by Isidorus of the Fayum, an author whose life and works are little known. ${ }^{15}$ This hymn was inscribed, along with three other devotional poems dedicated to Isis, at the south gate of a large Greco-Egyptian temple in the village that is now called Medinet Madi, in the extreme southern part of the Fayum. As in the case of Apuleius, Isidorus celebrates Mother Isis, describing the many names that the various nations $\left(\varepsilon^{\prime} \theta v \eta\right)$ use to call and pray to her:

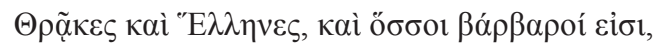

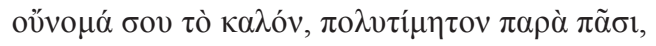


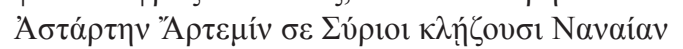

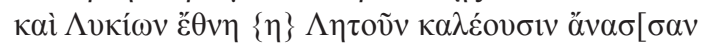

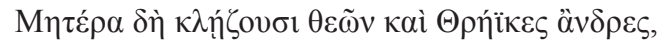

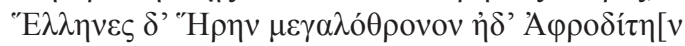

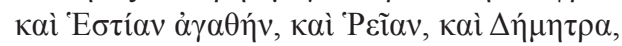

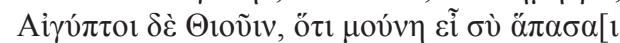

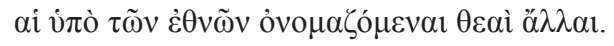

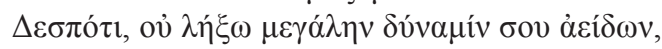

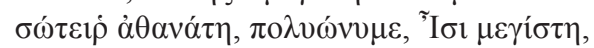
[...] (15-26)

Thracians, Greeks and Barbarians, Express your fair Name, a Name greatly honoured among all, (but) Each (speaks) in his own language, in his own land.

The Syrians call you: Astarte, Artemis, Nanaia,

The Lycians tribes call you: Leto, the Lady,

The Thracians also name You as Mother of the gods,

And the Greeks (call you) Hera of the Great Throne, Aphrodite,

Hestia the goodly, Rheia and Demeter.

But the Egyptians call You 'Thiouis' (because they know) that You, being One, are all

Other goddesses invoked by the races of men.

Mighty One, I shall not cease to sing of Your great Power,

Deathless Savior, many-named, mightiest Isis,

[...] (Tr. V.F. Vanderlip (1972: 18))

14 Apuleius' Metamorphoses translated by J. Arthur Hanson (1989).

15 The date of composition of the hymns is unknown. Vanderlip (1972:15) suggests that "the hymns could not have been composed later than the 80 's of the first century B.C., the last years of Soter's reign for, thereafter, they would have been foolishly anachronistic." 


\section{An originary goddess}

Aside from the semantic universe related to the verb voś $\omega$, the name Protennoia (lit. 'first thought') has a strong relation with the idea of primordiality. In several passages of the treatise, Protennoia appears as a primeval hypostasis, the first of created natures, but at the same time ambiguously as a creating nature herself. In 35, 4-6 she declares herself "the firstborn among those who came to be, [she who] exists before All." 16 After a few lines she states it again: "I am before [All, and] I am All, since I [am in] everyone [...] I exist from [the first]." ${ }^{17}$ Primordiality is a strong characteristic of Isis in aretalogical literature. In the second hymn of Philae, dating to the time of Ptolemy II Philadelphus (284-246 BCE) (Žabkar 1988:XV), Isis is described as the daughter of Geb, one of the most ancient Egyptian gods according to the Ennead of Heliopolis, in which he occupies a high position in terms of antiquity: "You are the First Royal Spouse of Onnophris, the supreme overseer of the Golden Ones in the temples, the eldest son, first(born) of Geb" (II, 4-6). In another aretalogy of Isis dating to the second or first century BCE (Grandjean 1975: 19), found in 1969 at Maronea on the northern coast of the Aegean sea, this genealogy is slightly changed:

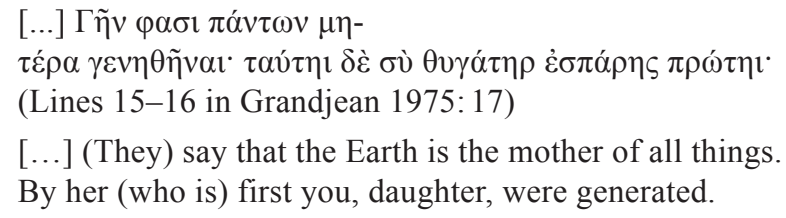

The idea that Isis is the daughter of $\Gamma \tilde{\eta}$, the Earth, is interesting: even though Isis is not presented as the daughter of the Greek equivalent of Geb (that is traditionally Chronos, which appears to be the father of Isis in two aretalogical passages presented by Diodorus Siculus),${ }^{19}$ nonetheless her antiquity and primordiality is still underlined. In this regard Grandjean (1975:46) writes: “En effet, jusq'alors, Isis se présentait, dans les arétalogies, comme la fille de Kronos. Pour les Grecs, Kronos était l'équivalent du dieu égyptien Geb, le dieu de la Terre qui fait pousser les plantes, tandis que Rhéa, l'épouse de Kronos, était identifiée à Nout, la déesse égyptienne du Ciel." According to Grandjean (1975:47-48), the author of the aretalogy described Isis as daughter of $\mathrm{Ge}$ - and not as daughter of Kronos as in the aretalogical tradition - precisely because they desired to underscore and celebrate the antiquity and the primordiality of Isis: "Dans le texte de Maronée, Isis n'est plus considérée comme la fille de Kronos, mais elle est appellée fille de Gé, la déesse grecque de la Terre [...] A quels motifs profonds répond ce changement? [...] L'auteur a voulu d'abord ajouter un surcroît de gloire à Isis en lui donnant Gé comme mère; ce faisant, en effet, il accentuait son ancienneté [...]."

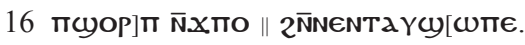

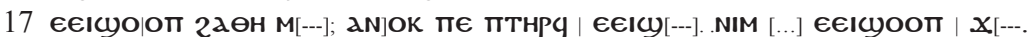

18 According to Egyptian mythology, there are nine fundamental gods who participated in the cosmogony. The first is Atum, followed by four dyads: Shu and Tefnut, Geb and Nut, Osiris and Isis, Seth and Nephthys. Geb not only belongs to this formation - the Great Ennead, which includes the most ancient gods - but he also occupies a high position, being separated from Atum, the most originary god, by only one generation (namely, the dyad $\mathrm{Shu} /$ Tefnut).

19 Bibl. Hist. I.27.3-5. Here Isis is twice stated to be the daughter of Chronos. 


\section{Universal goddess, Being of beings}

In the very opening of her hymn to herself, Protennoia describes her immanence in everything:

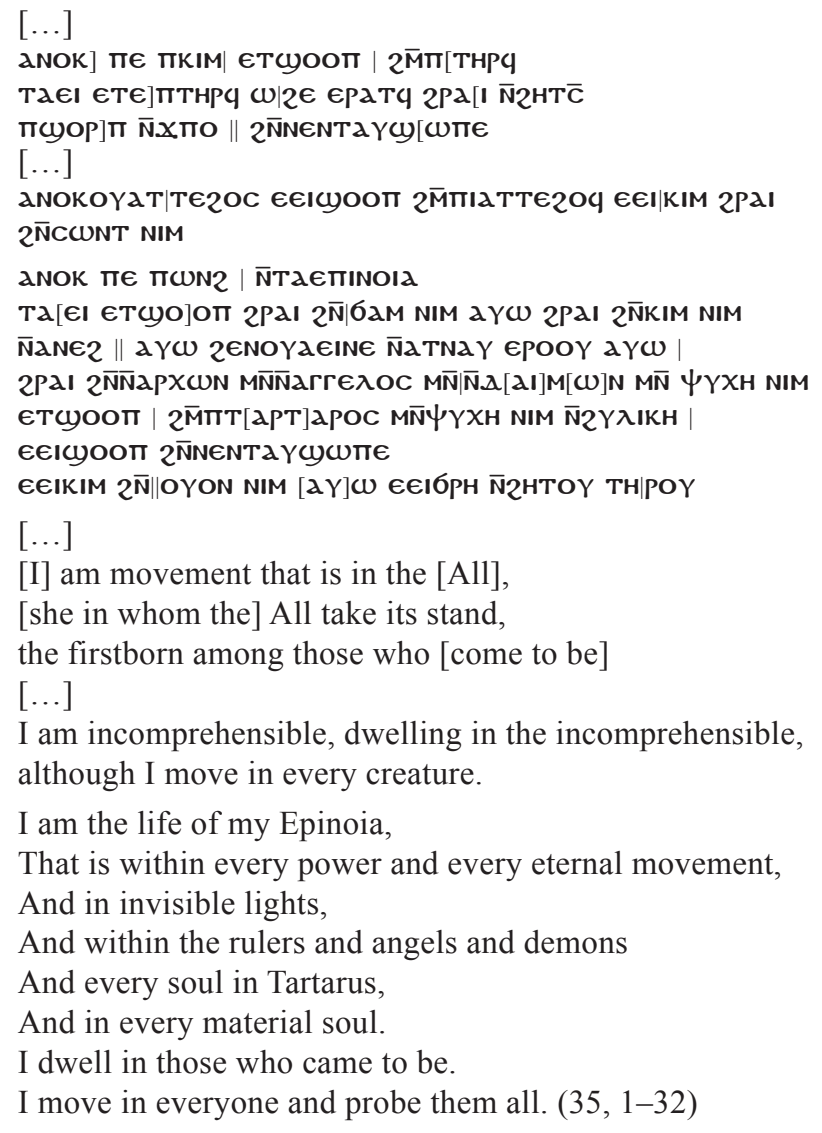

Protennoia is a hypostasis, the life of everything, the first metaphysical level of mediation between the primeval divine abyss and the created world. We can trace several theological ideas and mythical characters as possible forerunners of this divinity: from the biblical figure of Wisdom ${ }^{20}$ - itself probably shaped and influenced by Isiac theology ${ }^{21}$ - to the Platonic anima mundi. ${ }^{22}$ Of particular interest here are the dynamics of salvation that Protennoia can provide: through her revelation, human beings can remember and acknowledge that they ultimately belong to the heavenly, non-material world. This process is made possible because of the immanence of the divine hypostasis in humans:

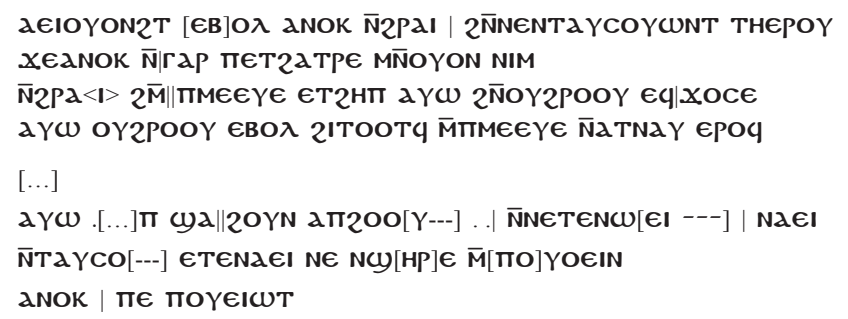

20 Cf. Ben Sira 24; Book of Wisdom 9.

21 About this, see footnote 3.

22 Platonic thought has played a fundamental role, along with the cult and the theology of Isis, in the shaping of this treatise. I hope to study this relationship in more depth in a future work. 
I, I revealed myself among all who recognize me,

for I am joined with everyone

through hidden thought and exalted [voice],

a voice from invisible thought. $(36,22-27)$

$[\ldots]$

From [the first day] until the day [I shall grant] mighty [power]

to those who are mine,

[I shall reveal myself to] those who have heard [my mysteries],

the children of light.

I am their father $[\ldots](40,34-41,2)$

The condition of union with the Godhead is constitutive of human beings as such, hence the salvation is nothing but the acknowledgment of this seed of divinity present in the soul. Those who are sensitive enough to perceive the voice of Protennoia calling to them from within are the "children of light":

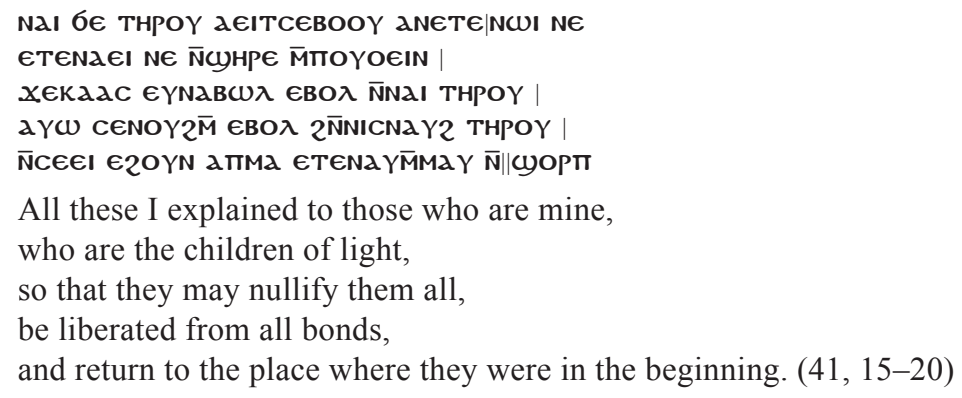

It is possible to interpret this obscure passage as follows: these particularly gifted men, called

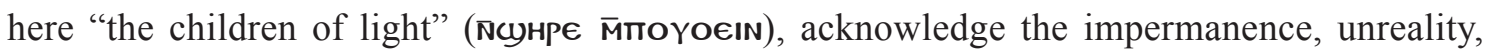
and meaninglessness of the physical world. Thus, they are liberated from the deceptions and bonds of this world, which hinder their path toward spiritual rebirth. Once they discover the truth that comes from within, they are able to soar again toward the realms of true life where they ultimately belong.

The panentheistic nature of Protennoia on which this soteriological system is based is mirrored in several Hellenistic and Imperial accounts of Isis as a universal and immanent divinity. In the fourth hymn to Isis engraved on the north wall of Room $\mathrm{X}$ in her temple in Philae, we can detect a record of the shift of Isis from goddess of fertility (especially the fertility brought by the inundations of the Nile) to Isis as universal goddess, present in everything that exists: ${ }^{23}$

(Indeed), She is the Lady of Heaven, Earth, and the Netherworld,

Having brought them into existence through what her heart conceived and

Her hands created,

She is the $B a$ ' that is in every city [...]

(Lines 10-13 in Žabkar 1988:51)

Commenting on his hymn, Žabkar (1988:52) writes: "If, in the preceding hymns, Isis was extolled as the divine mother and spouse, the lady of the palace, and the goddess of nature, here she appears as a universal supreme deity: she is the creator of the universe and providential sustainer of all life." Isis maintains everything in existence, like the soul does for the body. This

23 In other hymns of Philae, these traditional features of Isis are still preponderant (cf. III Hymn of Philae, 1. 9). 
idea shows the assimilation that took place in the Hellenistic period between Isis and Ma'at: as $\mathrm{Ma}$ 'at was the ancient hypostatization of the immanent order of the universe (Hart 2005: 89; Wilkinson 2003:150), Isis is the new one. Several other sources record the assimilation process between Ma'at and Isis. In the aretalogy of Kyme - dating between the first and the third century CE (Dieleman \& Moyer 2010:444) - Isis clearly appears as the guardian and the establisher of the cosmic order:

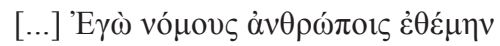

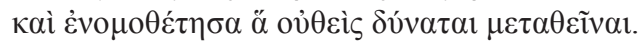

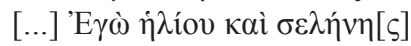

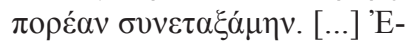

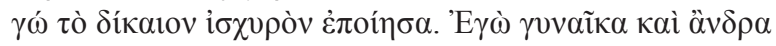

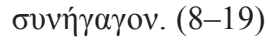

[...] I gave the laws to men

And the things I have legislated upon no one can change.

$[\ldots]$ of the Sun and of the Moon

I have ordered the path $[\ldots]$

I made strong what is right. I led together

The man and the woman. ${ }^{24}$

In the fifth hymn of Philae, the same nature of Isis as maintainer of order is described in a more dramatic way, namely, as the defender of the cycle of light and darkness. The hymn contains a brief mention that harkens back to the Egyptian myth of Apopis and the solar boat:

Mistress of flame who assaults the rebels,

Who slays Apopis in an instant,

Uraeus of Ra, the Coiled One upon his head,

Who gives orders in the barque of the King of Upper and Lower Egypt.

(Žabkar 1988: 58)

The horrible Apopis - who was traditionally the enemy of Ma' at (Spence 1915:131) - is the serpent-god of chaos, the "personification of the darkness of the darkest hour of night [...] the thick darkness which enveloped the watery abyss of Nu" (Budge 1904: 324). Apopis' aim is to destroy the solar boat during the twelve hours of night so as to hinder the return of light (Budge 1904:324). Slaying the enemy Isis - here called "Uraeus of Ra" - makes it possible for Ra to complete his cycle with the solar disc; thus, the light of day wins its eternal battle against the darkness and the sun returns to shine once again. Isis, the defender of the rhythm of night and day, stands here as the guardian of time and universal balance, playing exactly the role historically played by Ma' at. ${ }^{25}$

\footnotetext{
24 The translation is mine.

25 In the thirty-ninth chapter of the Book of the Dead, the same scenario of the cosmic battle is described. But here is Ma' at, not coincidentally by the side of Ra against Apopis: "Get thee back, Fiend, before the darts of his beams. Rā hath overthrown thy words, the gods have turned thy face backwards, the Lynx (Maftet), hath torn open thy breast, the Scorpion goddess [...] hath cast fetters upon thee, and Maāt hath sent forth thy destruction. Those who are in the ways have overthrown thee; fall down and depart, O Āpep, thou enemy of Rā." Translation in Budge 1904: 324.
} 


\section{ECHO OF A TOIOE OF EARLIER ARETALOGIES OF ISIS}

In Trim. Prot. 45, 6 we read: "Through me alone the All [stands firm]." Very similar ideas and expressions are found in Isiac literature. In the aforementioned aretalogy of Maronea (1.24-26), we read:

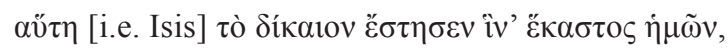

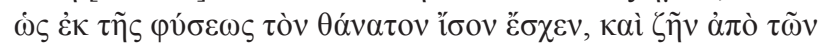

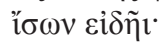

She established what is right so that each one of us,

As (they) have received an equal death by nature, may also know

A life (sustained) by equality.

Very similar passages are found in one of the three witnesses of the Memphite aretalogy, that of Kyme:

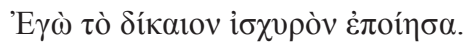

$[\ldots]$

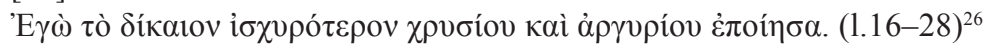

I made strong what is right

$[\ldots]$

I made what is right stronger than gold and silver.

This characteristic of Isis is likely itself a legacy of the ancient Egyptian goddess Ma'at, the hypostatization of universal order. In the third hymn of Philae (1.11-12), engraved by those mentioned above, she is once again described as "[She] who issues orders among the divine Ennead, according to whose command one rules." (Žabkar 1988:42)

\section{CONCLUSIONS}

The significant number of correspondences between the divine figure of Protennoia and Isis as described in aretalogical literature shows how, among the many religious worlds that are mirrored in the feminine Godhead of the Nag Hammadi treatise, ${ }^{27}$ there is also the Hellenistic and Imperial cult of Isis, which pervades the Christian text through a multiform web of literary echoes. Protennoia appears to share with Isis 1) being a goddess of knowledge; 2) polyonymy; being 3) a universal and 4) primeval divinity. In addition, 5) a trope of Isiac aretalogical literature - namely Isis as the guardian of universal stability - appears almost verbatim in the text of Trim. Prot. Determining how such literary dependencies and/or resonances may have happened would be extremely interesting, but unfortunately the data that scholars have collected so far do not allow us to answer these questions. Nonetheless, this study has endeavored to show how a synchronic approach can contribute to overcoming the impasse of the diachronic model. Through reception-oriented analysis, it was possible to show the continuity between the Isiac religion and the late ancient mysticism of the Trimorphic Protennoia (NHC XIII, 1).

\footnotetext{
26 Text in Engelmann 1976:98.

27 Similarities can be detected between Trim. Prot. and the Johannine prologue (see Poirier 2009: 93-104; Turner 1984:588-593), the Orphic hymns dedicated to female deities (see, for instance, Hekate, Rhea, Hera in Athanassakis \& Wolkow 2013), and, of course, the figure of biblical Wisdom discussed above.
} 


\section{REFERENCES}

Athanassakis, Apostolos N. \& Benjamin N. Wolkow 2013. The Orphic Hymns. Baltimore: John Hopkins University Press.

BAECHLER, Jean 1959. Recherches sur la diffusion des cultes isiaques en Italie du IIe s. av. J.-C. au IIe s. ap. J.-C. $\mathrm{PhD}$ dissertation, University of Strasbourg.

Bakhtin, Mikhail 1986. The Problem of Speech Genres. In: C. Emerson \& M. Holquist (eds): 60-102.

Bammel, Ernst (ed.) 1970. The Trial of Jesus. London: SCM Press.

Barnstone, Willis (ed.) 1984. The Other Bible. San Francisco: Harper Collins.

Borghouts, Joris F. 1978. Ancient Egyptian Magical Texts. (Nisaba 9) Leiden: Brill.

Budge, Ernest A.W. 1904. The Gods of the Egyptians: Or, Studies in Egyptian Mythology, I. London: Methuen \& Co.

Chance, James B. 1998. Divine Prognostications and the Movement of Story: An Intertextual Exploration of Xenophon's Ephesian Tale and the Acts of the Apostles. In: R.F. Hock, B.J. Chance, \& J. Perkins (eds): 219-234.

Clauss, James J. \& Martine CuYpers (eds) 2010. A Companion to Hellenistic Literature. Chichester: Wiley-Blackwell.

Conzelmann, Hans 1964. Die Mutter der Weisheit. In: E. Dinklet (ed.):225-234.

Croy, N. Clayton 2014. A God by Any Other Name: Polyonymy in Greco-Roman Antiquity and Early Christianity. Bulletin for Biblical Research 24(1):27-43.

Denzey Lewis, Nicola 2001. Genesis Traditions in Conflict?: The Use of Some Exegetical Traditions in the "Trimorphic Protennoia" and the Johannine Prologue. Vigiliae Christianae 55(1): 20-44.

DenZey Lewis, Nicola 2012. Introduction to Gnosticism: Ancient Voices, Christian Worlds. Oxford: OUP.

DeWANDEL, Albert 1941-1942. Geschiedenis van den Isiscultus in het westersche romeinsche Rijk. PhD dissertation, Leiden University.

Dieleman, Jacco \& Ian S. Moyer 2010. Egyptian Literature. In: J.J. Clauss \& M. Cuypers (eds): 429-447.

DinkLEt, Edward (ed.) 1964. Zeit und Geschichte: Dankesgabe an Rudolf Bultmann zum 80 Geburtstag. Tübingen: Mohr.

Dodson, Derek S. 2002. Dreams, the Ancient Novels, and the Gospel of Matthew: An Intertextual Study. Perspectives in Religious Studies 29(1):39-52.

Emerson, Caryl \& Michael Holquist (eds) 1986. Speech Genres and Other Late Essays. Austin: The University of Texas Press.

Engelmann, Helmut 1976. Die Inschriften von Kyme. (Inschriften griechischer Stadte aus Kleinasien 5) Bonn: Habelt.

ERICKSON, Frederick 1986. Listening and Speaking. In: D. TANnen \& J.E. Alatis (eds): 294-319.

Fossum, Jarl 1995. The Image of the Invisible God: The Influence of Jewish Mysticism on Early Christianity. Freiburg: Universitätsverlag.

Grandjean, Yves 1975. Une nouvelle arétalogie d'Isis à Maronée. (Études préliminaires aux religions orientales dans l'Empire romain 49) Leiden: Brill.

GumPerZ, John J. 1982. Discourse Strategies. Cambridge: CUP.

Gumperz, John J. 2001. Interactional Sociolinguistic: A Personal Perspective. In: D. Schiffrin, D. Tannen, \& H.E. Hamilton (eds): 215-228.

HalvgaArd, Tilde B. 2012. Linguistic Manifestations of Divine Thought. PhD dissertation, University of Copenhagen (later published (2015) as Linguistic Manifestations in the Trimorphic Protennoia and the Thunder: Perfect Mind: Analysed Against the Background of Platonic and Stoic Dialectics. Leiden: Brill.

Hanson, Arthur J. 1989. Apuleius: Metamorphoses. Cambridge, MA: HUP.

HART, George L. 2005. The Routledge Dictionary of Egyptian Gods and Goddesses. London: Routledge.

Hedrick, Charles \& Robert Hogdson Jr. (eds) 1986. Nag Hammadi, Gnosticism, and Early Christianity. Peabody, MA: Hendrickson.

Hedrick, Charles W. (ed.) 1990. Nag Hammadi Codices: XI, XII, XIII. (Nag Hammadi Studies 28) Leiden: Brill.

Hengel, Martin 1969. Judentum und Hellenismus: Studien zu ihrer Begegnung unter besonderer Berücksichtigung Palästinas bis zur Mitte des 2. Jh. v. Chr. (Wissenschaftliche Untersuchungen zum Neuen Testament 10) Tübingen: Mohr.

Hernandez-Campoy, Juam Manuel \& Juan Camilo Conde-Silvestre (eds) 2012. The Handbook of Historical Linguistics. Oxford: John Wiley \& Sons. 
Неyoв, Sharon K. 1975. The Cult of Isis among Women in the Graeco-Roman World. (Études préliminaires aux religions orientales dans l'Empire romain 51) Leiden: Brill.

Hock, Ronald F., Bradley J. Chance, \& Judith Perkins 1998. Ancient Fiction and Early Christian Narrative. Atlanta: Scholars Press.

MacRae, George W. 1970. The Ego-Proclamations in Gnostic Sources. In: E. Bammel (ed.): 122-134.

MacRae, George W. 1986. Gnosticism and the Church of John's Gospel. In: C. Hedrick \& R. Hodgson Jr. (eds): 89-96.

Malaise, Michel 1972. Les Conditions de pénétration et de diffusion des cultes égyptiens en Italie. (Études préliminaires aux religions orientales dans l'Empire romain 22) Leiden: Brill.

Malaise, Michel 2005. Pour une terminologie et une analyse des cultes isiaques. Brussels: Académie royale de Belgique.

MARBöCK, Johannes 1999. Weisheit im Wandel: Untersuchungen zur Weisheitstheologie bei Ben Sira. (Beihefte zur Zeitschrift für die alttestamentliche Wissenschaft 272) Berlin: de Gruyter.

MeYer, Marvin 2007. The Nag Hammadi Scriptures: The International Edition. NY: Harper Collins.

Nevalainen, Terttu 2015. What are Historical Sociolinguistics? Journal of Historical Sociolinguistics 1:243-269.

Nevalainen, Terttu, \& H. Raumolin-Brunberg 2012. Historical Sociolinguistics: Origins, Motivations, and Paradigms. In: J.M. Hernandez-Campoy \& J.C. Conde Silvestre (eds): 22-40.

NiKAIDO, Scott 2001. Hagar and Ishmael as Literary Figures: An Intertextual Study. Vetus Testamentum 51(2): $219-242$.

Painchaud, Louis \& Pierre-Hubert PoIrier (eds) 2006. Coptica, Gnostica, Manichaica: Mélanges offerts à WolfPeter Funk. Québec: Presses de l’Université Laval-Peeters.

Pleyte, Willem \& Francesco Rossi 1869-1876. Papyrus de Turin. Leiden: Brill.

PoIrIER, Paul-Hubert 1995. Le tonnerre, intellect parfait (NH VI, 2). Québec: Presses de l'Univeristé Laval.

PoIRIER, Paul-Hubert 2006. La Pensée première à la triple forme (NH XIII, 1). Quebéc: Presses de l'Univeristé Laval.

PoIRIER, Paul-Hubert 2009. The Trimorphic Protennoia (NHC XIII, 1) and the Johannine Prologue: A Reconsideration. In: T. Rasimus (ed.): 93-104.

Prato, Gian L. 1998. Sapienza e Torah in Ben Sira: Meccanismi comparativi culturali e conseguenze ideologicoreligiose. Rivista di Studi Biblici 10:129-151.

Rasimus, Tuomas (ed.) 2010. The Legacy of John. Leiden: Brill.

Robinson, James M. 1984. The Facsimile Edition of the Nag Hammadi Codices. Leiden: Brill.

Robinson, James M. (ed.) 1988. The Nag Hammadi Library in English. Leiden: Brill.

Robinson, James M. (ed) 2000. The Coptic Gnostic Library: A Complete Edition of the Nag Hammadi Codices, V. Leiden: Brill.

SAnders, Jack T. 1982. On Ben Sira 24 and Wisdom's Mother Isis. In: Proceedings of the Eighth World Congress of Jewish Studies, Jerusalem, August 16-21, 1981, Division A: The Period of the Bible:73-78. Jerusalem: World Union of Jewish Studies.

Schenke, Gesine 1974. Die dreigestaltige Protennoia: Eine gnostische Offenbarungsrede in koptischer Sprache aus dem Fund von Nag Hammadi eingeleitet und übersetzt vom Berliner Arbeitkreis für koptisch-gnostische Schriften. Theologische Literaturzeitung 99: col. 731-746.

Schiffrin, Deborah, Deborah Tannen, \& Heidi E. Hamilton (eds) 2001. The Handbook of Discourse Analysis. Chichester: Wiley-Blackwell Publishing.

Spence, Lewis 1915. Myths \& Legends of Ancient Egypt. London: Harrap.

Streete, Gail C. 2000. An Isis Aretology from Kyme in Asia Minor, First Century BCE. In: R. VAlantAsis (ed.):369-383.

Soukup, Barbara 2017. Historical Sociolinguistic Philology: A New Hybrid Discipline, its Interests, and its Scope. Open Linguistics 3:673-678.

TAKÁCS, Sarolta A. 1994. Isis and Sarapis in the Roman World. Leiden: Brill.

TANNEn, Deborah \& James E. Alatis (eds) 1986. Languages and Linguistics. Washington: Georgetown University Press.

Tran-TAm-Tinh, Vincent 1964. Essai sur le culte d'Isis à Pompéi. Paris: E. de Boccard.

Tran-tam-Tinh, Vincent 1972a. Le culte des divinités orientales en Campanie: en dehors de Pompéi, de Stabies et d'Herculanum. (Études préliminaires aux religions orientales dans l'Empire romain 27) Leiden: Brill.

Tran-TAM-Tinh, Vincent 1972b. Le culte des divinités orientales à Herculaneum. Leiden: Brill.

TuRCAN, Robert 1989. Les cultes orientaux dans le monde romain. (Histoire 2) Paris: Belles Lettres. 
Turner, John D. 1984. Trimorphic Protennoia. In: W. Barnstone (ed.): 588-593.

Turner, John D. 1988. Trimorphic Protennoia (XIII, 1). In: J.M. Robinson (ed.): 511-523.

Turner, John D. (ed.) 2000. Trimorphic Protennoia. In: J.M. Robinson (ed): 371-457.

Turner, John D. 2006. The Sethian Baptismal Rite. In: L. Painchaud \& P.-H. Poirier (eds):941-992.

Valantasis, Richard (ed.) 2000. Religions of Late Antiquity in Practice. Princeton: PUP.

VANDERLIP, Vera Frederika 1972. The Four Greek Hymns of Isidorus and the Cult of Isis. (American Studies in Papyrology 12) Toronto: Hakkert.

Whybray, Roger N. 1995. The Book of the Proverbs: A Survey of Modern Study. (History of Biblical Interpretation Series 1) Leiden: Brill.

Wilkinson, Richard H. 2003. The Complete Gods and Goddesses of Ancient Egypt. London: Thames \& Hudson.

ŽABKAR, Louis V. 1988. Hymns to Isis in her Temple at Philae. Hanover: Brandeis University Press. 